44-2 | 2019

Varia

\title{
Eoin Swithin Walsh, Kilkenny: In Times of Revolution, 1900-1923
}

John Borgonovo

\section{(2) OpenEdition}

1 Journals

Édition électronique

URL : https://journals.openedition.org/etudesirlandaises/8689

DOI : 10.4000/etudesirlandaises.8689

ISSN : 2259-8863

\section{Éditeur}

Presses universitaires de Caen

\section{Édition imprimée}

Date de publication : 31 décembre 2019

Pagination : 161-162

ISBN : 978-2-84133-964-8

ISSN : 0183-973X

\section{Référence électronique}

John Borgonovo, «Eoin Swithin Walsh, Kilkenny: In Times of Revolution, 1900-1923 », Études irlandaises [En ligne], 44-2 | 2019, mis en ligne le 06 mai 2020, consulté le 15 novembre 2022. URL : http:// journals.openedition.org/etudesirlandaises/8689; DOI : https://doi.org/10.4000/etudesirlandaises. 8689

\section{(c) (†)(อ)}

Creative Commons - Attribution - Pas d'Utilisation Commerciale - Partage dans les Mêmes Conditions 4.0 International - CC BY-NC-SA 4.0

https://creativecommons.org/licenses/by-nc-sa/4.0/ 
This compilation of testimonies by journalists can be considered as a memorial in itself and will be added to the archives of other testimonies that have been gathered over the last twenty years to be studied by future historians.

Fabrice MOURLON

\section{Eoin Swithin Walsh, Kilkenny: In Times of Revolution, 1900-1923, Newbridge, Merrion Press, 2018, 350 p.}

The recent death of Professor David Fitzpatrick has deprived modern Irish history of one of its most important scholars. A remarkable researcher and an incisive writer, Fitzpatrick helped pioneer Irish Diaspora and First World studies, mentoring a talented generation of historians in the process. Perhaps Fitzpatrick's greatest contribution was his work on Revolutionary Ireland, most notably his groundbreaking study of County Clare, Politics and Irish Life, 1913-1921: Provincial Experience of War and Revolution (Dublin, Gill \& Macmillan, 1977). His novel approach inspired important local studies by historians like Peter Hart, Joost Augusteijn, Marie Coleman, Michael Farry, and Padraig Yates, to just name a few. Still following Fitzpatrick's model three decades later, Four Courts Press's "The Irish Revolution, 1912-1923” series (edited by Mary Ann Lyons and Daithí Ó Corráin) has expanded our understanding of the revolutionary experience by producing local studies (nine and counting) of less-obvious counties like Louth, Monaghan, and Waterford. The Four Courts series reuses the same rough template in terms of periodisation (19131923) and focus (social/ economic as well as political/military), which allows for easy comparisons between the counties. While the field becomes more crowded, space remains for different approaches to the county study. One such example is Eoin Swithin Walsh's new book, Kilkenny: In Times of Revolution, 1900-1923.

In terms of revolutionary intensity, County Kilkenny has been relegated to the second division by historians, who have generally accepted Ernie O'Malley's description of the Kilkenny IRA "slack" during the War of Independence. Eoin Swithin Walsh does not fundamentally revise that interpretation, but he adds considerable nuance to it. The work can be characterised primarily as a military history, mostly relating to the 1919 to 1923 period, despite the title. The methodology is somewhat conventional and narrow, though it does produce some gems. Of note is an examination of republican governance during the War of Independence, primarily via local bodies and the Dáil Éireann underground administration. The author incorporates Cumann na mBan into his main narrative, as a featured participant rather than in a passing cameo. Gender-based violence also receives notice, including hair-shorning, a topic Linda Connolly has recently drawn attention to. The author should be especially praised for identifying every violent death in County Kilkenny during the War of Independence and Civil War. This kind of pain-staking research is a service to both scholars and the interested public. Frequently the narrative is enlivened by entertaining portraits of 
events and personalities. My favourite concerns the colourful National Army General John Prout during the "Battle of Limerick City", who prowled the city encouraging his troops accompanied throughout by his pistol-packing 12-year-old son.

The book is well-written, but its analysis is sometimes uneven. The author does a good job of pulling together and commenting on local electoral, economic and social data. Unfortunately, Swithin Walsh only rarely compares Kilkenny to other counties, connects his narrative into regional or national frameworks, or draws on the extensive scholarship within the field. Labour and agrarian dimensions of the struggle are also under-developed. The author makes good use of newspapers, compensation claims, inquest reports, and the Irish government's Bureau of Military History Witness Statements and Military Service Pension Collection records. However, the British perspective is often missing due to limited engagement with various Royal Irish Constabulary reports and British Army records and official histories. Missing entirely are the Ernie O'Malley oral interviews with IRA veterans relating to Kilkenny (held at the University College Dublin archives), which are necessary to draw a full picture of Civil War developments in the region.

Perhaps the book's most important sections relate to the Civil War and the few months immediately prior to the outbreak of fighting. A full chapter is devoted to providing a definitive account of the "Battle of Kilkenny", a two-day clash between pro and anti-Treaty forces in early May 1922. The Kilkenny fighting gave urgency to republican (pro and anti-Treaty) peace negotiations in Dublin, which led to proposed power-sharing arrangements within the IRA (the Army Unification Plan) and Sinn Fein (an election "pact" prior to the June 1922 General Election). Though largely forgotten today, these developments briefly appeared to have diverted the Irish Free State from fratricide. The proposed peace settlement did not come to pass, but it should be considered, as Heather Laird has recently described, "a road not taken". As such, this section of the book is of particular relevance to scholars working in the field.

The Civil War chapters are straightforward, if narrowly argued. They will add significantly to Civil War scholarship, which remains relatively under-developed. The overall fatality count of twenty-six Civil War deaths in Kilkenny compares to twenty-two during the War of Independence, with periodic dramatic and bloody episodes occurring well into 1923. Using a strong empirical basis, the author convincingly argues that while the Kilkenny IRA possessed a modest "fighting record" (especially when compared to units in neighbouring Tipperary), county residents experienced serious social disruptions throughout the period, which are briefly explored in the final chapter.

Despite certain shortcomings, Eoin Swithin Walsh has produced a valuable study of County Kilkenny. The book illuminates a neglected area of revolutionary Ireland, and helps inform our understanding of the Civil War. The author should be commended for a work which pushes the scholarship further along a path first laid out by the late David Fitzpatrick over forty years ago. 